\title{
Study of somatic embryogenesis in leaf explants of sap- indus emarginatus vahl
}

\author{
Srinivas Devaraju' ${ }^{1}$, K. Jaganmohan Reddy ${ }^{2}$ \\ ${ }^{1}$ Dept. of Botany, Telangana University, Nizamabad, Andhra Pradesh, India \\ ${ }^{2}$ Dept. of Botany, Kakatiya University, Warangal, Andhra Pradesh, India
}

Email address:

devarajusrinu@gmail.com (S. Devaraju)

To cite this article:

Srinivas Devaraju, K. Jaganmohan Reddy. Study of Somatic Embryogenesis in Leaf Explants of Sapindus Emarginatus Vahl. Agriculture, Forestry and Fisheries .Vol. 2, No. 1, 2013, pp.33-37. doi: 10.11648/j.aff.20130201.14

\begin{abstract}
Plant regeneration through Somatic embryogenesis has several advantages over other routes to in vitro plant production and appears that most promising area of research for large scale production and rapid plant propagation. Sapindus emarginatus vahl commonly known as soap nut tree wherein the nut shell contains saponin, which acts like soap when comes in contact with water. It has very high economic and medicinal values in saponin industry and is also being used for important medicinal properties. The present study is aimed on somatic embryogenesis from leaf explants of Sapindus emarginatus Vahl employing auxin such as 2, 4-D along with cytokinin BAP/Kn. The present protocol is the first ever reported of its kind and is unique in itself as the latex poses a threat for tissue culture.
\end{abstract}

Keywords: Leaf Explants, Sapindus Emarginatus, Somatic Embryogenesis

\section{Introduction}

Somatic embryos are believed to originate from a single cell and therefore plants derived from these tend to be genetically identical (Tomer and Gupta 1986). Plant regeneration through somatic embryogenesis has several advantages over other routes to in vitro plant production and appears the most promising area of research for large scale production and rapid plant propagation. The first report of somatic embryogenesis in carrot tissue cultures in vitro was published by Steward et al. (1958) and Reinert (1958; 1959). Somatic embryogenesis can be induced directly from a variety of explants or obtained indirectly by manipulating in vitro non-embyrogenic callus. The totipotency of cells finds best expression in the formation of somatic embryos from single cells and their growth and development to form a complete plantlet (Attree and Fowke 1993; Finer 1994).

Sapindus emarginatus Vahl is commonly known as soap nut tree. It has very high economic and medicinal values in saponin industry and is also being used for important medicinal properties. It forms a soft, smooth layer on the skin which protects against infections and insects. Soap nut is a natural exfoliant. It is considered to be second to none and is also very common in the Indian Ayuverdic healing system. The saponin moiety is characterized as hederagenin group of glycosides. The root bark is also saponaceous and is also used a detergent, in the same way as the fruits In fact, the skin of the fruit is highly valued by the rural folks as a naturally produced shampoo used for washing the hair, because of which the village women call soapnut as "Skin Beautifier and Freckle Remover".

As soap nut fruit is so rich in iron, it is considered as a hemolytic and is often used to treat anemia, cure chlorosis and epilepsy. It is also used as an expectorant for severe lung congestion and also promote blood circulation in patients with low blood pressure. Ritha or Soap nut is a sedative to the uterus and is used to ease childbirth. It can also be prepared as a digestive aid, anti-venom for snake bite, or to treat diarrhea, cholera and paralysis.

\section{Materials and Methods}

\subsection{Plant Material}

Young plants of Sapindus emarginatus Vahl were collected and grown under partly shade conditions in the experimental garden of the Aromatic and Medicinal Plants, Department of Botany, Kakatiya University, Warangal. The leaf explants were collected from one year old healthy plants. The leaf explants were washed in a mild non phytotoxic liquid detergent (2\% Labolene) stirred for about 3 
min and then washed in tap water. It was followed by a dip in a $0.1 \%(\mathrm{w} / \mathrm{v})$ mercuric chloride $\left(\mathrm{HgCl}_{2}\right)$ solution for 2 minutes. Finally the leaf explants were washed thoroughly with sterile water before the inoculation onto the sterilized nutrient agar media prepared in culture tubes. All the above operations were performed under aseptic conditions in a laminar air flow cabinet.

\subsection{Culture Media and Culture Conditions}

Leaf explants of different sizes $(0.5-10 \mathrm{~mm})$ were cultured with the abaxial surface in contact with induction medium consisting of MS salts, vitamins, $6 \%$ sucrose $(0.5-$ $3.0 \mathrm{mg} / \mathrm{L}), \mathrm{BAP} / \mathrm{Kn}$ in combination with $2,4-\mathrm{D}(0.5-$ $1.0 \mathrm{mg} / \mathrm{L}$ ) maintaining a $\mathrm{pH}$ of 5.7- 5.8. The percentage of responding explants was evaluated after 4 weeks of culture. Responses scored were the percentage of explants containing the embryos in the globular stage. All the cultures were incubated under $16 / 8 \mathrm{~h}$. light/ dark photoperiod at $25 \pm 2^{\circ} \mathrm{C}$ a light intensity of $40 \mu \mathrm{mol} \mathrm{m}-2^{\mathrm{s}-1}$ and provided with coolwhite florescent tubes. The cultures were transferred to fresh medium after an interval of 4 weeks. For germination and plantlet formation somatic embryos were transferred to MS medium supplemented with IAA (0.5-1.0 mg/L) + BAP $(0.5-3.0 \mathrm{mg} / \mathrm{L})$ and incubated under the same culture conditions.

\section{Results}

Results on somatic embryogenesis in Sapindus emarginatus Vahl are presented in Tables 1- 2 and the review of somatic embryogenesis in medicinal plants is presented in Table-1. Leaf cultured on various concentrations of 2, 4-D (0.5-1.0 $\mathrm{mg} / \mathrm{L})$ in combination with $\mathrm{BAP} / \mathrm{Kn}$ (0.5-3.0 $\mathrm{mg} / \mathrm{L})$ produced swollen and generally de differentiated and developed friable callus after 15- 20 days of culture. Within 25-30 days of culture, globular embryos had formed directly on the surface or primary embryos were cut in to fragments and cultured on the same induction medium and secondary somatic embryos were induced within three weeks. Somatic embryos appeared in this medium on the surface of a callus, 25-30 days after the culture initiation (Plate I), a period that was shorter than that observed for induction from zygotic embryo $(1.0 \mathrm{mg} / \mathrm{L})$ from explants. The best results were obtained when leaf explants were initially cultured with $2,4-\mathrm{D}$ and $\mathrm{Kn}(2.0 \mathrm{mg} / \mathrm{L})$, with an induction frequency of $83 \%$, a higher value than those obtained from zygotic embryos, which could be expected in a more differentiated tissue, such as that of leaves.
Table 1. Effect of Various concentrations of 2,4-D and BAP on Somatic embryogenesis in Leaf explants of Sapindus emarginatus Vahl.

\begin{tabular}{lll}
\hline $\begin{array}{l}\text { Hormone } \\
\text { concentration } \\
\text { (mg/L) }\end{array}$ & $\begin{array}{l}\text { \% of cultures } \\
\text { responding }\end{array}$ & $\begin{array}{l}\text { Average number } \\
\text { of somatic } \\
\text { embryos/explants } \\
\pm(\text { S.E.)* }\end{array}$ \\
\hline $\mathbf{2 , 4 - D + B A P}$ & & $5.3 \pm 0.35$ \\
\hline $0.5+0.5$ & 40 & $7.3 \pm 0.045$ \\
$0.5+1.0$ & 50 & $8.3 \pm 0.37$ \\
$0.5+1.5$ & 60 & $12.3 \pm 0.27$ \\
$0.5+2.0$ & 70 & $10.2 \pm 0.37$ \\
$0.5+2.5$ & 55 & $7.5 \pm 0.34$ \\
$0.5+3.0$ & 40 & $5.0 \pm 0.37$ \\
$1.0+0.5$ & 50 & $7.0 \pm 0.34$ \\
$1.0+1.0$ & 65 & $8.5 \pm 0.34$ \\
$1.0+1.5$ & 75 & $13.5 \pm 0.32$ \\
$1.0+2.0$ & 80 & $10.3 \pm 0.33$ \\
$1.0+2.5$ & 72 & $8.5 \pm 0.75$ \\
\hline $1.0+3.0$ & 62 & \\
\hline
\end{tabular}

* Mean \pm Standard Error

Table 2. Effect of Various concentration of 2,4-D and Kn on Somatic embryogenesis in Leaf explants of Sapindus emarginatus Vahl.

\begin{tabular}{|c|c|c|}
\hline $\begin{array}{l}\text { Hormone } \\
\text { concentration } \\
(\mathrm{mg} / \mathrm{L})\end{array}$ & $\begin{array}{l}\% \text { of cultures } \\
\text { responding }\end{array}$ & $\begin{array}{l}\text { Average number } \\
\text { of somatic } \\
\text { embryos/explants } \\
\pm \text { (S.E.)* }\end{array}$ \\
\hline \multicolumn{3}{|l|}{ 2,4-D+Kn } \\
\hline $0.5+0.5$ & 45 & $6.3 \pm 0.36$ \\
\hline $0.5+1.0$ & 53 & $8.0 \pm 0.45$ \\
\hline $0.5+1.5$ & 65 & $10.0 \pm 0.36$ \\
\hline $0.5+2.0$ & 73 & $13.0 \pm 0.37$ \\
\hline $0.5+2.5$ & 58 & $12.0 \pm 0.36$ \\
\hline $0.5+3.0$ & 42 & $7.8 \pm 0.32$ \\
\hline $1.0+0.5$ & 54 & $6.2 \pm 0.38$ \\
\hline $1.0+1.0$ & 68 & $8.5 \pm 0.34$ \\
\hline $1.0+1.5$ & 76 & $9.5 \pm 0.34$ \\
\hline $1.0+2.0$ & 83 & $15.0 \pm 0.34$ \\
\hline $1.0+2.5$ & 73 & $12.0 \pm 0.34$ \\
\hline $1.0+3.0$ & 65 & $10.3 \pm 0.65$ \\
\hline
\end{tabular}

* Mean \pm Standard Error 


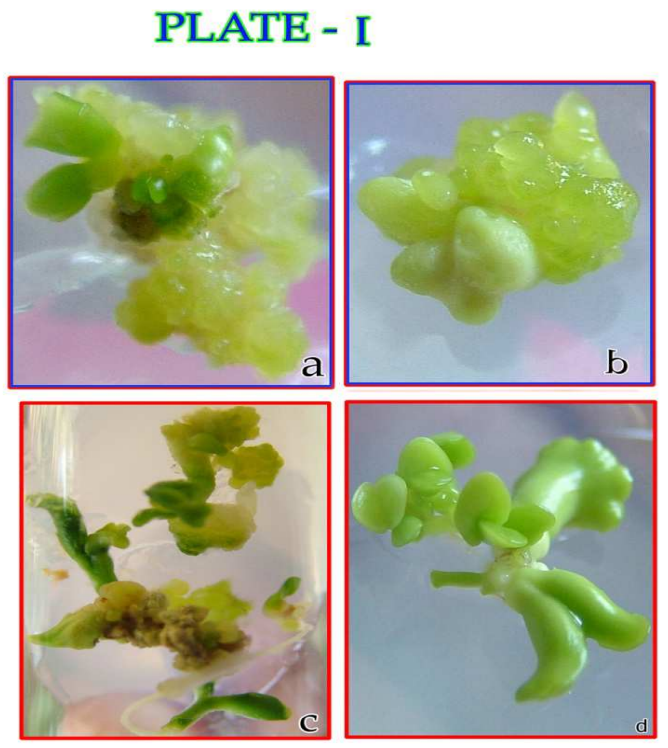

Plate - I. $a=$ somatic embryos (Globular and cotyledonary) formation; $b=$ different stages of somatic embryo formation; $c=$ germination of somatic embryos into planlets; $d$ = germination of somatic embryos into planlets (mature).

\subsection{Effect of 2,4-D +BAP}

Leaf explants were cultured on MS medium containing $30 \mathrm{~g} / \mathrm{L}$ sucrose amended with various concentration of 2,4$\mathrm{D}(1.0 \mathrm{mg} / \mathrm{L})$ in combination with BAP $(0.5-3.0 \mathrm{mg} / \mathrm{L})$. Somatic embryogenesis was induced in all combinations and concentrations tested but exhibited varied results (Table -1$)$. High percentage of somatic embryogenesis $(80 \%)$ was observed at 2, 4-D $(1.0 \mathrm{mg} / \mathrm{L})+$ BAP $(2.0 \mathrm{mg} / \mathrm{L})$ which produced 13.5 \pm 0.32 embryos/explants (Plate II and III). As concentration of BAP increased the somatic embryo induction percentage was reduced.

\section{PLATE - II}
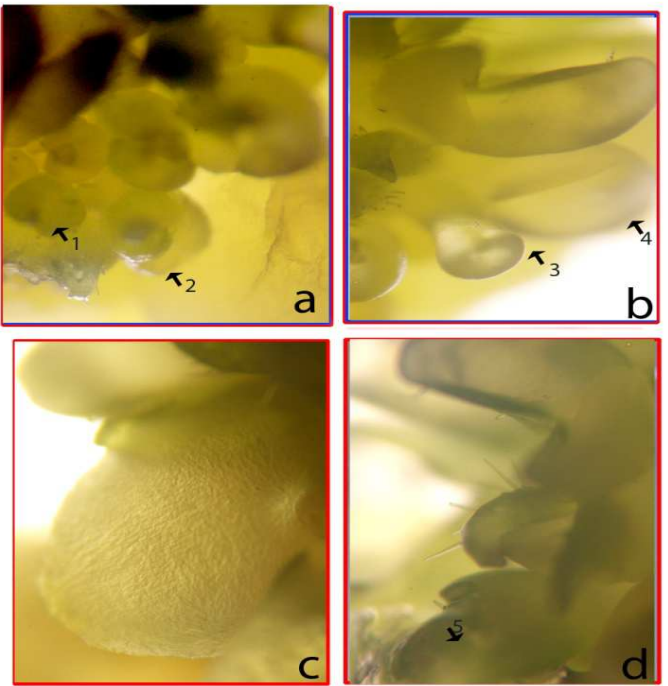

Plate -II. $a, b, c, d=$ Stereomicroscopic images of different stages of somatic embryos.

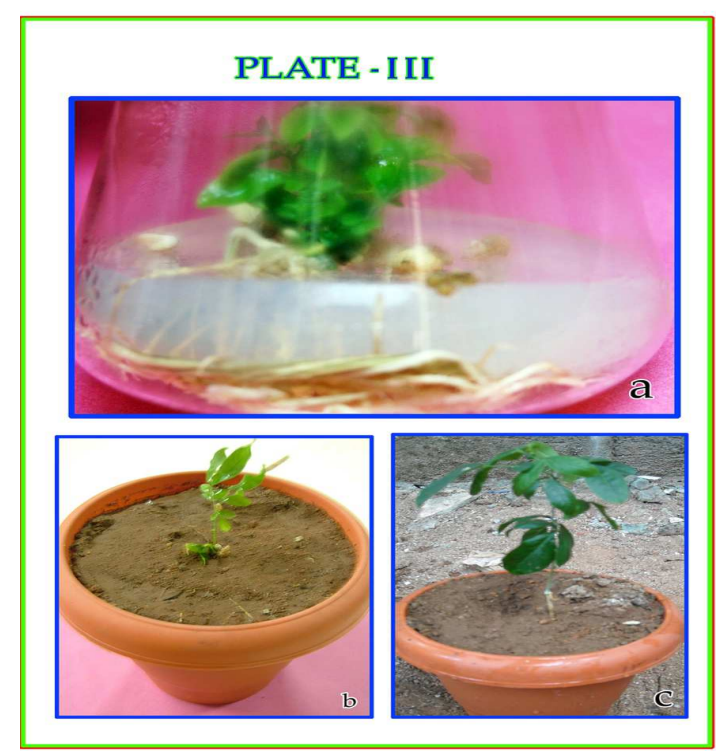

Plate-III . a = Proliferation of rooting on $M S+0.5 \mathrm{mg} / \mathrm{L} \mathrm{IBA;b=Har-}$ dened regeneration after 4 weeks; $c=$ hardened regeneration after 6 weeks.

Leaf explants when cultured on MS medium containing $30 \mathrm{~g} / \mathrm{L}$ sucrose amended with various concentration of 2,4$\mathrm{D}(0.5 \mathrm{mg} / \mathrm{L})$ in combination with $\operatorname{BAP}(0.5-3.0 \mathrm{mg} / \mathrm{L})$ showed maximum percentage of somatic embryogenesis around $70 \%$ at $2,4-\mathrm{D}(0.5 \mathrm{mg} / \mathrm{L})+\mathrm{BAP}(2.0 \mathrm{mg} / \mathrm{L})$ which produced (12.3 \pm 0.27 embryos/explants. At 2, 4-D (0.5 $\mathrm{mg} / \mathrm{L})+\operatorname{BAP}(0.5-3.0 \mathrm{mg} / \mathrm{L})$ lesser response was observed than 2,4-D $(0.5 \mathrm{mg} / \mathrm{L})+\operatorname{BAP}(0.5-3.0 \mathrm{mg} / \mathrm{L})$.

\subsection{Effect of 2, 4-D +Kn}

Leaf explants were cultured on MS medium containing $(30 \mathrm{~g} / \mathrm{L})$ sucrose amended with various concentration of BAP $(0.5-3.0 \mathrm{mg} / \mathrm{L})$ in combination with 2 , $4-\mathrm{D}(0.5 \mathrm{mg} / \mathrm{L})$. Somatic embryogenesis was induced in all combinations and concentrations tested but varied results $(0.5 \mathrm{mg} / \mathrm{L})(\mathrm{Ta}-$ ble-2). High percentage of somatic embryogenesis (73\%) was observed at $2,4-\mathrm{D}+\mathrm{Kn}(2.0 \mathrm{mg} / \mathrm{L})$ which produced $13.0 \pm 0.37$ embryos/explants (Plate II). It was further observed that as concentration of $\mathrm{Kn}$ increased the somatic embryo induction percentage was reduced.

Leaf explants when cultured on MS medium containing $(30 \mathrm{~g} / \mathrm{L})$ sucrose amended with various concentration of $\mathrm{Kn}$ $(1.0-3.0 \mathrm{mg} / \mathrm{L})$ in combination with $\mathrm{Kn}(1.0 \mathrm{mg} / \mathrm{L})$ showed maximum percentage of somatic embryogenesis around $83 \%$ at $2,4-\mathrm{D}(1.0 \mathrm{mg} / \mathrm{L})+\mathrm{Kn}(2.0 \mathrm{mg} / \mathrm{L})$ which produced $15.0 \pm 0.34$ embryos/explants. At concentrations of 2,4-D $(0.5 \mathrm{mg} / \mathrm{L})+\mathrm{Kn}(0.5-3.0 \mathrm{mg} / \mathrm{L})$ lesser response was observed than the 2,4-D $(1.0 \mathrm{mg} / \mathrm{L})+\mathrm{Kn}(0.5-3.0 \mathrm{mg} / \mathrm{L})$.

Further, the somatic embryos with various developmental stages (heart and Globular) were further sub cultured on fresh MS medium containing various concentration of BAP $(0.5-1.0 \mathrm{mg} / \mathrm{L})$ in combination with IAA $(0.5-3.0 \mathrm{mg} / \mathrm{L})$ for germination of somatic embryos induced from leaf explants. Of these, media tested MS + IAA $(1.0 \mathrm{mg} / \mathrm{L})+\mathrm{BAP}$ 
$(2.0 \mathrm{mg} / \mathrm{L})$ proved to be the best for somatic embryo germination and plantlet formation after 4 weeks of culture (Table 3).

Table 3. Effect of IAA in combination with various concentration of BAP on the conversion of Somatic embryoids into Plantlets in Sapindus emarginatus Vahl.

\begin{tabular}{lll}
\hline $\begin{array}{l}\text { Hormone } \\
\text { concentration } \\
\text { (mg/L) }\end{array}$ & $\begin{array}{l}\text { \% of cultures } \\
\text { responding }\end{array}$ & $\begin{array}{l}\text { Frequency of } \\
\text { Somatic } \\
\text { embryos (S.E)* }\end{array}$ \\
\hline IAA+BAP & 60 & $07.3 \pm 0.36$ \\
\hline $0.5+0.5$ & 63 & $09.0 \pm 0.45$ \\
$0.5+1.0$ & 68 & $12.0 \pm 0.36$ \\
$0.5+1.5$ & 75 & $14.0 \pm 0.37$ \\
$0.5+2.0$ & 70 & $10.0 \pm 0.36$ \\
$0.5+2.5$ & 68 & $08.8 \pm 0.32$ \\
$0.5+3.0$ & 62 & $09.2 \pm 0.38$ \\
$1.0+0.5$ & 65 & $10.5 \pm 0.34$ \\
$1.0+1.0$ & 70 & $12.5 \pm 0.34$ \\
$1.0+1.5$ & 78 & $15.0 \pm 0.34$ \\
$1.0+2.0$ & 63 & $11.0 \pm 0.34$ \\
$1.0+2.5$ & 50 & $10.3 \pm 0.65$ \\
$1.0+3.0$ & & \\
\hline
\end{tabular}

* Mean \pm Standard Error

\section{Discussion}

In the present investigation, the results on somatic embryogenesis have shown that auxin such as 2,4-D along with cytokinin $\mathrm{BAP} / \mathrm{Kn}$ are essential for induction of somatic embryogenesis from cotyledon explants of Sapindus emarginatus Vahl, where in the growth regulators play a primary role in the medium for induction of somatic embryogenesis in nature. The type of auxin or auxin in combination with cytokinin used in the medium can greatly influence somatic embryo frequency. Proliferated embryogenetic suspension cultures were established in Sapindus emarginatus Vahl. This regeneration system may be widely applicable. However the magnitude of several tissues (induction, growth, embryo yield, germination and conversion) essential for efficient plant recovery was different among the Sapindus emarginatus Vahl.

Various studies have documented genotype effects on induction of somatic embryo genesis from immature cotyledon explants of soybean using a variety of protocols (Parrott et al., 1989; Shoemaker et al., 1991.) The development stage of cotyledon is known to be critical for induction of somatic embryogenesis (Lazzeri et al. 1985; Ranch et al. 1985) and hence explants were prepared from immature seeds of 3-5 $\mathrm{mm}$ in length. However, selection of explants from uniform seeds many not have ensured uniform deve- lopmental status among genotypes differing in mature seed size. These genotypic differences for induction capacity might be altered by selection of explants based on criteria other than equal seed length. The selected immature embryos for culture were one half of the length of mature seeds.

Reddy and Reddy (1993) have reported the improved response of auxin like 2, 4-D alone for induction of somatic embryogenesis compared to combination of 2, 4-D and cytokines in Arachis hypogea. Somatic embryogenesis is generally believed to be triggered by an auxin and for many plants, 2, 4-D has been widely regarded to be effective for somatic embryogenesis (Ammirato 1983; Finer, 1988). Similarly Binzal et al. (1996) reported that the entire process of induction and maturation of the embryos was completed on the same MS medium containing auxin and cytokinins (2, 4-D + TDZ) in Capsicum annuum as it was observed the requirement of both the hormones in the investigations. Further, somatic embryo maturation on MS medium containing the combination of auxins $(2,4-\mathrm{D})$ and cytokinins (BAP) was observed in Cajanus cajan (Mallikarjuna et al. 1996).

\subsection{Embryo Maturation and Germination}

In the present investigation leaf explants showed maximum percentage of somatic embryogenesis and high frequency of somatic embryo induction / explant (15.0 \pm 0.34$)$. The calli developed from leaf explants containing globular embryoes were transferred to maturation medium containing MS medium supplemented with 2,4-D (0.5 - $1.0 \mathrm{mg} / \mathrm{L})$ $+\mathrm{BAP} / \mathrm{Kn} 2.0 \mathrm{mg} / \mathrm{L}$ respectively.

Auxin and auxin like substitutes are mainly used for the in vitro induction of somatic embryogenesis in various crops (Litz and Gray 1995). Although Picloram, Dicamba, NAA, 2, 4, 5-T are being used to induce embryogenesis, 2, 4-D is the most commonly used auxin exploited for various crops (Fitch 1990). Cytokinin induced somatic embryogenesis is rare but has also been achieved (Maheshwaran and Williams 1986; Gill and Saxena 1992). Recently, TDZ has also been found to induce somatic embryogenesis (Murty et al. 1998). Thus it can br emphatically stated that remarkable progress has been made in the commercialization of somatic embryogenesis since its discovery in carrot by Steward et al. (1958). There are also a few recent reports on induction of somatic embryogenesis in presence of cytokinins like Thidiazuron (Saxena et al. 1997) and BAP (Malik and Saxena 1992).

\section{Acclimatization}

The embryos turned green with folded cotyledons, which subsequently developed into whole plantlets. Only fully matured embryos when transferred to MS basal medium without growth regulators, produced good shoot and root systems with $20 \%$ frequency, but not the heart-shaped ones. This implies that embryos need to mature enough for ger- 
mination on basal medium. Complete plantlets were developed on MS basal medium containing BAP $(2.0 \mathrm{mg} / \mathrm{L})$ in combination with IAA $(1.0 \mathrm{mg} / \mathrm{L})$ within three weeks from somatic embryos. Plantlets regenerated via somatic embryos were transferred to half strength MS liquid medium without hormones for two weeks for hardening. A total of 300 regenerants were transferred to polycups containing a mixture of soil and sand in a ratio of 3: 1 with $75 \%$ survival rate. A total of 200 regenerated plants were transferred to the pots from the polycups with $80 \%$ survival along with seed raised controls. Tissue culture-regenerated plants produced normal flowers and set seeds while no morphological variations were observed.

\section{References}

[1] Ammirato PV (1983).The regulation of somatic embryos development in plant cell cultures, suspension cultures technique and hormone requirements. Bio. Technol. 1: 68-74.

[2] Attree SM and Fowke LC (1993). Embryogeny of gymnosperms advances in synthetic seed technology of Conifers. Plant Cell Tissue Org. Cult. 35: 1-35.

[3] Binzel ML, Sanhla AN, Joshi S and Sankhla D (1996). In vitro regeneration in chili pepper (Capsicum annuum L.) from half-seed explant. Plant Growth Regul. 20: 287-293.

[4] Gill R and Saxena PK (1992). Direct somatic embryogenesis and regeneration of plants from seedling explants of peanut (Arachis hypogeae) promotive role of thidiazuron. Can. J. Plant Sci. 70:1186-1192.

[5] Finer JJ (1988). Apical proliferation of embryogenic tissue of soyabean (Glycine max L.) Plant Cell Reports. 7: 238-241.

[6] Finer JJ (1994). Plant regeneration via embryo genic suspersion cultures. In: Plant Cell Cultures. A practical approach. Dixon RA and Gonzales RA (eds) Oxford University Press, Oxford, pp. $67-102$.

[7] Fitch MM (1990). High frequency Somatic embryogenesis and plant regeneration from papaya hypocotyl callus. Plant Cell Tiss.Org. Cult. 32: 205-212.

[8] Lazzeri PA, Hildebrand DF Collins GB (1985). A procedure for plant regeneration from immature cotyledon tissue of soybean. Plant Mol. Biol. Rep. 3:160-167.

[9] Litz RE and Gray (1995). In vitro Somatic embryogenesis from Mangifera indica L. Callus. Sci. Hort. 22: 233-240.

[10] Maheshwaran G and Williams EG (1986). Primary and Secondary Direct Somatic Embryogenesis from Immature Zygotic Embryos of Brassica campestris. J. Plant Physiol. 124: 455-463.

[11] Malik KA and Saxena PK (1992). Somatic embryogenesis and shoot regeneration from intact seedlings of Phaseolus acutifolius, P. aureus, P. coccineus and P. wrightii. Plant Cell Rep. 11: 163-168.

[12] Mallikarjuna N, Reena MJT, Sastri DC and Moss JP. (1996). Somatic embryogenesis in Pigeonpea Cajanus cajan L. Indian J. Exp. Biol. 34: 282-284.

[13] Murthy BNS, Murch SJ and Saxena PK (1998). Thidiazuron: A potent Regulator of in vitro plant morphogenesis in vitro cell development. Biol. Plant. 34: 267-275.

[14] Ranch JP, Oglesby L, Zielinski AC, (1985). Plant regeneration from embryo derived tissue cultures of soybean. In $\mathrm{Vi}$ tro Cell Dev. Biol. 21: 653-658.

[15] Reddy P and Reddy S (1983) Scope for Production rise. The Hindu Survey of Indian Agriculture.

[16] Reinert J (1958) Uber die Kontrolle der morphogenese und die Inducan von Adventive embronen an Gewebekulturen aus Karotten. Planta 53: $318-333$.

[17] Reinert J (1959). Uber die kontrolle der morphogenese and die inductionVon Advientive, embryonen \& Gewebekuluren aus kartten. Planta 58: 318-333.

[18] Saxena C, Palai SK, Samantaray S, Rout GR and Das P (1997). Plant regeneration from callus cultures of Psoralea corylifolia Linn. Plant Growth Regul. 22: 13-17.

[19] Shoemaker RC, Amberger LA and Palmer RG (1991). Effects of 2, 4-Dichlorophenoxy acetic acid on somatic embryogenesis and heritable variation in soybean (Glycine max (L.) Merr.) in vitro. Cell Dev. Biol. 27: 84-88.

[20] Steward FC, Mcpes MG and Meass K (1958). Growth \& organized development of cultured cell organization in cultured grown from freely suspended cells. Amer. J. Bot. 445: 705-708.

[21] Parrott WA, Hoffmann LM, Hildebrand DR, Williams EG and Collins GB (1989). Recovery of primary transformaonts of soybean. Plant Cell Rep. 7: 615- 617.

[22] Tomar UK. and Gupta SC (1986). Somatic embryogenesis and organogenesis in callus cultures of a free legume Albizzia richardiana King. Plant Cell Rep. 7: 70-73. 